\title{
Św. Brygida Szwedzka, bitwa pod Grunwaldem i założenie Klasztoru Triumphus Mariae w Lublinie
}

Kilkanaście lat temu, polski uczony Zenon Ciesielski napisał artykuł o Św. Brygidzie (Birgitta) Szwedzkiej w Roczniku Instytutu Polsko-Skandynawskiego (Polish-Scandinavian Research Institute) w Kopenhadze, w którym wspomniał również o założeniu trzech klasztorów Sióstr Brygidek w Gdańsku, Lublinie i Elblągu'. W naszym studium przyjrzymy się bliżej okolicznościom założenia drugiego z tych klasztorów, to jest klasztoru Triumphus Mariae w Lublinie. Poczynając od samej postaci szwedzkiej prorokini i późniejszej św. Brygidy - Birgitty Birgersdotter ${ }^{2}$ (1303-1373), przez bitwę pod Grunwaldem (Tannenberg, Žalgiris) w 1410 r., omówimy założenie klasztoru w Lublinie, co miało miejsce w latach 1412-1426. Chociaż podstawowe fakty znane są w polskich i skandynawskich badaniach historycznych, warto jednak zebrać je uwzględniając część bogatej literatury przedmiotu. Dobrym wprowadzeniem do biografii Brygidy jest angielska praca autorstwa Bridget Morris z 1999 r. ${ }^{3}$ W 1996 r. Tore Nyberg założył przegląd naukowy Birgittiana, gdzie publikuje się artykuły po angielsku, niemiecku, włosku, hiszpańsku, i wydał już dwadzieścia jeden tomów tego czasopisma ${ }^{4}$. Istnieje oczywiście obszerna literatura współczesna w języku szwedzkim, na przykład znakomita publikacja rocznicowa „Birgitta av Vadstena”, wydana w 2003 r. ${ }^{5}$

${ }^{1}$ Z. Ciesielski, Św. Brygida - patronka Szwecji, Skandynawii i Europy, ,Rocznik Instytutu Polsko-Skandynawskiego" t. 15, 1999/2000 (Copenhagen, 2000), s. 51-60.

${ }^{2}$ Czyli „Birgitta, córka Birgera (Petersson)““.

${ }^{3}$ B. Morris, St Birgitta of Sweden, Studies in Medieval Mysticism, 1, Woodbridge 1999.

${ }^{4}$ Birgittiana, red. T. Nyberg (Odense, Dania), Neapol 1996 -. Por. L. Kwiatkowska-Frejlich, The iconographical motive of the 'Genealogical Tree of Saint Birgitta' in a painting of the former Birgittine church w Lublinie, tamże, 15-16, 2003, s. 117-138.

${ }^{5}$ Birgitta av Vadstena. Pilgrim och profet 1303-1373. En jubileumsbok 2003, red. P. Beskow, A. Landen, Stockholm 2003. 


\section{Objawienia Św. Brygidy i ich rozpowszechnianie się na Czechy, Polskę i Prusy}

Dzięki intensywnym badaniom prowadzonym przez ToreNyberga ${ }^{6}$, Stefanię Kamińską $^{7}$, Carla-Gustafa Undhagena ${ }^{8}$, Edwarda Potkowskiego ${ }^{9}$, Birgera Bergha ${ }^{10}$, Hansa Aili1 ${ }^{11}$, Pavlínę Rychterovą ${ }^{12}$ oraz innych badaczy, obecnie bardzo dobrze orientujemy się w procesie rozpowszechniania się Revelationes Św. Brygidy w Czechach, Polsce i Prusach. Około roku 1380 wielu wykształconych ludzi udawało się do Rzymu, aby zdobyć kopie jej pism, wśród nich Nuncius studii Pragensis ${ }^{13}$. Wydaje się przeto prawdopodobne, że Uniwersytet Praski posiadał przynajmniej jeden cenny rękopis jej proroctw na początku lat 80-tych XIV w. Kanonizacja Brygidy przez papieża Bonifacego IX w dniu 7 października 1391 r. niewątpliwie spowodowała, że jej objawienia stały się znane i cenione, zwłaszcza w kręgach popierających reformę kościoła. Podobno miały stanowić obok Biblii ulubioną lekturę cesarza Wacława IV ${ }^{14}$.

Co się tyczy Polski, to ważną rolę w popularyzacji tam pism Św. Brygidy odegrał słynny Mateusz z Krakowa (Matheus de Cracovia) ${ }^{15}$. Był on członkiem komisji złożonej z kardynałów i uczonych teologów, powołanej przez papieża Grzegorza XI w celu zbadania Reguły Brygidy i jej objawien. To chyba właśnie on otrzymał słynny „rękopis warszawski” w 1378/79 r. ${ }^{16}$ Po trwającej kilka stuleci odysei przez Pragę, Kraków, Warszawę, Sankt Petersburg, Paryż i Kanadę, cenny rękopis wrócił do

${ }^{6}$ T. Nyberg, Birgittinische Klostergründungen des Mittelalters, Bibliotheca historica Lundensis, 15, Lund-Leiden 1965. Kolejne dzieła Nyberg będą przedstawione poniżej. Zob. także Medieval Spirituality in Scandinavia and Europe. A Collection of Essays in Honour of Tore Nyberg, ed. L. Bisgaard, C. S. Jensen, K. Villads Jensen, J. Lind, Odense 2001, s. 343-350 (Bibliografia opublikowanych prac Tore Nyberga).

${ }^{7}$ S. Kamińska, Klasztory brygidek w Gdańsku, Elblagu i Lublinie. Założenie i uposażenie, Gdańskie Towarzystwo Naukowe. Wydział i Nauk Społecznych i Humanistycznych. Seria monografii, 38 , Gdańsk 1970.

${ }^{8}$ C.-G. Undhagen, General introduction [and] Special introduction, w: Sancta Birgitta. Revelaciones, Book I, with Magister Mathia's Prologue, ed. C.-G. Undhagen, Stockholm 1977, s. 1-37 i 38226. - także w serii: Samlingar utg[ivna] av Svenska Fornskriftssällskapet. Ser. 2. Latinska skrifter, VII:I, Uppsala 1978.

${ }^{9}$ E. Potkowski, Krytyka i reforma. Teksty publicystyki kościelnej w Polsce XV wieku, w: Literatura i kultura późnego średniowiecza w Polsce, red. T. Michałowska, Warszawa 1993, s. 177-196. - Autor (S. E.) dziękuje Profesorowi Potkowskiemu za nadbitkę artykułu.

${ }^{10} \mathrm{~B}$. Bergh, Visionernas väg: de birgittinska uppenbarelsernas texthistoria, w: Birgitta av Vadstena, s. 45-52.

${ }^{11}$ H. Aili, Handskrifterna till Birgittas revelationer, w: Brigitta av Vadstena, s. 53-72.

${ }^{12}$ P. Rychterová, Die Offenbarungen der heiligen Birgitta von Schweden. Eine Untersuchung zur alttschechischen Übersetzung des Thomas von Štitné (um 1330 - um 1409), Beihefte zum Archiv für Kulturgeschichte, 58, Kolonia, Weimar, Wiedeń 2004.

${ }_{13}$ C.-G. Undhagen, General introduction, s. 31; H. Aili, Handskrifterna, s. 60-61.

${ }^{14}$ P. Rychterová, Die Offenbarungen, s. 85-86.

${ }^{15}$ Mistrz Mateusz był nauczycielem na uniwersytecie Praskim a potem profesorem teologii i rektorem (1397) Uniwersytetu w Heidelbergu. W 1405 r. mianowano go biskupem Wormacji, gdzie zmarł w $1410 \mathrm{r}$.

${ }^{16}$ H. Aili, Handskrifterna, s. 60-62. 
Polski w 1959 roku i przechowywany jest obecnie w Bibliotece Narodowej w Warszawie $^{17}$. Dzięki wstawiennictwu Mateusza z Krakowa, niektórych uczonych z Uniwersytetu Praskiego zaproszono na dwór królewski w Polsce, gdzie przebywali w latach 1392-1400 ${ }^{18}$. Jak wykazał Edward Potkowski, kompletne teksty, fragmenty i różnego rodzaju adaptacje proroctw Św. Brygidy znajdują się nie tylko wielkich bibliotekach państwowych, ale także w zbiorach prywatnych i bibliotekach katedralnych, kościelnych i klasztornych ${ }^{19}$. Dokładny inwentarz zachowanych rękopisów w różnych krajach sporządził i ich związki zbadał Carl-Gustaf Undhagen w swej pracy „Special Introduction” z 1977 r., którą można uzupełnić użytecznym, aktualnym streszczeniem autorstwa Hansa Aili.

Wedle polskiego kronikarza, Jana Długosza (1415-1480), król Władysław Jagiełło zlecił przetłumaczenie wielu dzieł religijnych z łaciny na polski dla swej młodej żony Jadwigi, w tym objawień Św. Brygidy ${ }^{20}$. Zważywszy na fakt, że Jadwiga zmarła w 1399 roku, tłumaczeń tych zapewne dokonano przed końcem XIV w. Kilka zachowanych fragmentów proroctw w języku polskim, pochodzących z połowy XV w. być może powstało w oparciu na tym wczesnym tłumaczeniach. ${ }^{21}$ Revelationes były zatem dobrze znane w Europie Środkowej na początku XV w (na przełomie XIV i XV.). ${ }^{22}$

Podobnie w Prusach, gdzie powstało najstarsze opactwo Brygidek, oprócz głównego w Vadstena w Szwecji (1384), i Santa Maria w Paradiso we Włoszech (1394). Było nim Marienbrunn - Fons Mariae - w Gdańsku, założone w 1396 r. przez Konrada von Jungingen, wielkiego mistrza krzyżackiego, w istniejącym wcześniej Domu Pokutnic ("Haus der Büßerinnen") obok kaplicy Marii Magdaleny ${ }^{23}$. Tamtejsi bracia i zakonnice byli również dobrze zaznajomieni z pismami św. Brygidy. Sześćdziesiąt lat później założono jeszcze jeden klasztor Brygidek w Prusach - w Elblągu. Nazwano go Marienfriede, Maria Pacis. Św. Brygida była faktycznie nie mniej

17 Tamże. Przynajmniej 30 cennych kopi napisano i iluminowano w specjalnym pomieszczeniu -skryptorium w Neapolu, ale tylko trzy z nich zachowały się. Rękopis przechowywany w Bibliotece Narodowej w Warszawie (MS 3310) jest najstarszy. Pozostałe dwa są własnością biblioteki Pierpont Morgan Library w Nowym Jorku i biblioteki Biblioteca centrale della Regione siciliana w Palermo.

${ }_{18}$ Tamże. Zob. także C.-G. Undhagen, General introduction, s. 31-33; S. Kamińska, Klasztory brygidek, s. 159-160: E. Potkowski, Krytyka i reforma, s. 185-187; P. Rychterová, Die Offenbarungen, s. 90-99 i passim.

${ }^{19}$ E. Potkowski, Krytyka i reforma, s. 186-188, szczególnie przyp. 34-40.

${ }^{20}$ [Długosz, Annales, X.] Joannis Dlugossii Annales seu Cronica incliti regni Poloniae, liber decimus et liber undecimus, 1370-1405. Textum recensuit et moderavit D. Turkowska. Adiutrice M. Kowalczyk. Commentarium confecit S. Perzanowski, Warszawa 1985, p. 232.

${ }^{21}$ J. Łoś, Dwa teksty staropolskie. I. Objawienia św. Brygidy, Materiały i Prace Komisji Jezykowej AU, 5, Kraków 1912, s. 425-433; E. Potkowski, Krytyka i reforma, s. 187-188.

${ }^{22}$ Zob. także M. Kowalczyk, Mowy i kazania uniwersyteckie Łukasza z Wielkiego Koźmina, „Biuletyn Biblioteki Jagiellońskiej”, t. 12, 1960, 2, s. 7-20, szczególnie 9, 12, 17-18.

${ }^{23}$ T. Nyberg, Birgittinische Klostergründungen; tenże, Nowe prace o zakonie brygidek $w$ Prusach i Rzeczpospolitej, „Zapiski Historyczne”, t. 39, 1974, 4, s. 75-83; tenże, Das Birgittenkloster in Danzig bis Ende 1402, „Zeitschrift für Ostforschung”, t. 40, 1991, s. 161-225; tenże, Die Birgittiner von Danzig im baltischen Beziehungssystem des Ordens 1403-1410, w: Balticum. Studia z dziejów polityki, gospodarki i kultury XII-XVII wieku, ofiarowane Marianowi Biskupowi w siedemdziesiąta rocznicę urodzin, red. Z. H. Nowak, Toruń 1992, s. 241-253. 
znana w Prusach niż w Polsce, nie tylko dzięki swoim pismom, ale także z powodu faktu, że drewnianą trumnę z jej szczątkami uroczyście przywieziono z Rzymu do Gdańska, a potem dalej do Vadstena w 1373/74 r. Już w 1374 roku, nuncius cruciferorum, zapewne prokurator krzyżacki przy Stolicy Apostolskiej, dostarczył kopie jej objawień. Rękopisy te przechowywano w klasztorze w Oliwie, potem w klasztorze w Pelplinie a także w kościele Św. Mikołaja w Elblągu ${ }^{24}$.

Wśród czcicieli św. Brygidy była Dorothea z Montau (1347-1394), patronka Zakonu Krzyżackiego i Prus, której Św. Brygida jawiła się jako „wzór i ideał ("Muster und Vorbild"') 25.

Przez prawie 500 lat, naukowcy prowadzący badania na temat Św. Brygidy polegali na pierwszym drukowanym wydaniu (księgi) jej proroctw. Wydał ją w 1492 r. w Lubece Bartholomaeus Ghotan pod tytułem Revelationes celestes na zlecenie opactwa w Vadstena ${ }^{26}$. Dzisiaj wszakże teksty łacińskie dostępne są w znakomitych szwedzkich wydaniach krytycznych, z których „Księga II”, wydana w 2001, interesuje nas najbardziej $^{27}$. Dostępne jest również szwedzkie tłumaczenie Tryggve Lundéna ${ }^{28}$. Nowe tłumaczenie angielskie Denisa Searby ze wstępem i przypisami autorstwa Bridget Morris, którego pierwszy tom opublikowano w 2006, jest prawie na ukończeniu ${ }^{29}$.

\section{Krytyka Krzyżaków (cruciferi) w proroctwie św. Brygidy}

Jedno z proroctw Św. Brygidy (Birgitty Birgersdotter) zawiera wypowiedź polityczną, która, jak się okazało, miała większy wpływ na Europę Środkową i region Bałtyku niż Brygida to przewidziała. Znajduje się w Rozdziale 19, w którym Chrystus ostro krytykuje krzyżowców czyli Krzyżaków (cruciferi), którzy wedle Niego (a więc i Brygidy) myśleli tylko o sobie, a na różne sposoby zaniedbywali i uciskali dawnych pogan. $Z$ tego powodu mieli być surowo ukarani. Powiedział Chrystus:

${ }^{24}$ Das Leben der heiligen Dorothea von Johannes Marienwerder, wyd. M. Toeppen, w: Scriptores rerum Prussicarum. Die Geschichtsquellen der Preußischen Vorzeit bis zum Untergange der Ordensherrschaft, II, Leipzig 1863, s. 179-350, szczególnie s. 257-258, przyp. 2.

${ }_{25}$ Tamże. Zob. także S. Kamińska, Klasztory brygidek, s. 54-57, 63, 81 oraz P. Rychterová, Die Offenbarungen, s. 91. Por. Liber de festis magistri Johannis Marienwerder. Offenbarungen der Dorothea von Montau, wyd. A. Triller, Forschungen und Quellen zur Kirchen- und Kulturgeschichte Ostdeutschlands, 25, Cologne, Weimar, Vienna 1992. s. $1-37$.

${ }^{26} \mathrm{Na}$ temat różnych redakcji oraz wydania z 1492 zob. C.-G. Undhagen, General Introduction,

${ }^{27}$ [Birgitta. Revelationes, II.] Sancta Birgitta. Revelaciones, Book II, wyd. C.-G. Undhagen, B. Bergh, Stockholm 2001. (także w: Samlingar utgivna av Svenska fornskriftsällskapet, Serie 2. Latinska skrifter, VII:2, Uppsala 2001). Szczegółowe informacje o wszystkich dziewięciu tomach (19562002), zob. Birgitta av Vadstena, s. 409.

${ }^{28}$ Den heliga Birgitta. Himmelska uppenbarelser. Till svenska av T. Lundén. [4 t.] Malmö 19571959.

${ }^{29}$ The Revelations of St. Birgitta of Sweden. Volume I: Liber Caelestis, Book I-III., tłum. D. Searby; ze wstepem i przypisami B. Morris, New York 2006. 
Deinde Filius michi loquebatur dicens: „Ostendi tibi supra de apibus, quod habent triplex bonum de apiastro suo. Dico tibi nunc, quod tales apes deberent esse illi cruciferi, quos in illis finibus terrarum Christianorum posui. Sed iam ipsi pugnant contra me. Nam de animabus non curant, non compaciuntur corporibus conuersorum ad fidem catholicam et ad me de errore. Opprimunt enim eos laboribus, priuant libertatibus, in fide non instruunt eos, sacramentis priuant et cum maiori dolore mittunt eos ad infernum quam si starent in suo assueto paganismo. Nec enim pugnant nisi ut dilatent superbiam suam et augeant cupiditatem suam. Ideo veniet eis tempus, quo confringentur dentes eorum, manus dextra mutilabitur, et subneruabitur dexter pes eorum, ut viuant et se ipsos cognoscant" (Birgitta, Revelaciones, II, p. 92).

Następnie Syn Boży zwrócił się do mnie, mówiąc: Tam patrząc na te pszczoły, pokazałem $\mathrm{Ci}$, że otrzymały one trzy korzyści od swej królowej. Powiadam Ci, że owi krzyżowcy [Krzyżacy], których postawiłem u granic krain chrześcijańskich, powinni być jak te pszczoły. Ale teraz oni walczą przeciwko mnie, albowiem nie dbają o dusze ani nie mają współczucia dla ciał tych, których nawrócono od błędu na wiarę katolicką i wiarę we mnie. Uciskają ich trudami i pozbawiają wolności. Nie nauczają ich w wierze lecz pozbawiają sakramentów i posyłają ich do piekła z gorszą karą, niż gdyby zostali przy swym tradycyjnym pogaństwie. Co więcej, walczą tylko po to, by powiększyć swą własną pychę i zwiększyć swą chciwość. Przeto nadchodzi czas, gdy będą zgrzytać zębami, okaleczona będzie ich prawą dłoń i odjęta prawa stopa, po to by żyli i poznali siebie samych (tłum. za The Revelations of St. Birgitta of Sweden, t. I, s. 226).

Birgitta otrzymała objawienia zawarte w drugiej księdze w Szwecji w latach 1344-1349. Odnoszą się one głównie do arystokracji i wyrażają w wielu rozdziałach wojujące ideały Św. Brygidy ${ }^{30}$. Oczywisty jest ich związek z rosyjskimi wyprawami szwedzkiego króla Magnusa Erikssona z lat 1348 i 1350/51¹. Brygida nie była pacyfistką, ale żądała, aby wojna była bellum iustum [wojną sprawiedliwą] i żeby król próbował najpierw metod pokojowych, by przekonał prawosławnych, że tylko wiara katolicka reprezentowała prawdziwe chrześcijaństwo. Nawiasem mówiąc,

\footnotetext{
do ks. II).

${ }^{31}$ Tamże; S. Ekdahl, Die Rolle der Ritterorden bei der Christianisierung der Liven und Letten, w: Gli inizi del cristianesimo in Livonia-Lettonia. Atti del colloquio internazionale di storia ecclesiastica in occassione del'VIII centenario della chiesa in Livonia (1186-1986), Roma, 24-25 Giugno 1986, Pontificio comitato di scienze storiche. Atti e documenti, I, red. M. Maccarrone, Città del Vaticano, s. 203-243, szczególnie s. 242-243; tenże, Die skandinavischen Königreiche zur Zeit Gediminas', w: Tarp istorijos ir bütovès. Studijos prof. Edvardo Gudavičiaus 70-mečiui, red. A. Bumblauskas, R. Petrauskas, Vilnius 1999, s. 37-54; O. Ferm, Heliga Birgittas program för uppror mot Magnus Eriksson. En studie i politisk agitationskonst, w: Heliga Birgitta - budskapet och förebilden. Föredrag vid jubileumssymposiet $i$ Vadstena 3-7 oktober 1991, Kungl. Vitterhets Historie och Antikvitets Akademien. Konferenser, 28, red. A. Härdelin, M. Lindgren, Stockholm 1993, s. 125-143. T. Nyberg, Birgitta politikern, w: Birgitta av Vadstena, s. 89-103; D. Harrison, Gud vill det! Nordiska korsfarare under medeltiden, Stockholm 2005, szczególnie s. 213-214.
}

${ }^{30}$ Den heliga Birgitta. Himmelska uppenbarelser, 1, Malmö 1957, s. 191 (T. Lundén, wstęp 
król Magnus Eriksson postąpił za jej radą, ale bez powodzenia ${ }^{32}$. Niekoniecznie, wszakże, znaczy to, że krytyka zawarta w rozdziale 19. była skierowana głównie wobec szwedzkiej szlachty toczącej walkę w kierunku wschodnim, i w każdym razie było oczywiste dla każdego, kto czytał objawienia poza Szwecją, że oskarżenia były wymierzone przeciw Zakonowi Krzyżackiemu, który rządził i dominował nad Bałtykiem od Estonii na północy po Prusy na południu. W długiej i roztropnej analizie warunków w Prusach, przedłożonej wielkiemu mistrzowi zakonu, Paulowi z Rusdorf w 1427 czy1428 przez zakonnika-kartuza i oznaczonej w badaniach niemieckich jako „Die Ermahnung des Carthäusers” ${ }^{33}$, ta część objawień Św. Brygida cytowana jest po niemiecku:

Nemet zcu hertczen, das dy selige Birgitta hie von hot geschreben, also ir Got selbst hot geoffenbart und geklaget ime anderen buche irer offenbarunge ime XIX cappittel, do der here zcu ir sprach: Ich habe dir vorgesaget von den benen, dy dreyerley nutcz sulden haben in dem benestocke. Aber nu sage ich dir, das semliche benen sullen seyn dy kreutcziger, dy ich gesatczt habe in dy orter der cristen lande, sunder sy fechten itczunt selber widder mich, in deme das sy nicht achten der zelen, ader mitteleydunge haben bey den, dy sy zcu deme gelouben bekart haben, sy besweren und underdrucken dy mit veler grosser arbeit, sy entfremden sy irer freyheit und underweisen sy nicht ime gelouben, sy benemen yn, das sy nicht gebrauchen der sacrament und senden dy myt grosser muge und vordrys in dy helle, wen ab sy gebleben weren in irer heydenschafft. Ouch krigen sy und fechten nicht anders, wen das sy auffrichten und breten ire hoffart und geyrickait. Dorummb wirt in komen dy zceit, das ire zcene sullen zcugruset werden, ire rechte hant sal in appgehauen werden, und ire rechte fus sal vorlemet werden, uff das sy sich noch irkennen und leben (Die Ermahnung des Carthäusers, p. 461).

Zakonnik powiada, że krytyka była wymierzona w Prusy i była uzasadniona. Kara została wymierzona, gdy Zakon Krzyżacki został pokonany w wielkiej bitwie pod Grunwaldem w 1410. Wielki mistrz i jego ludzie zostali zabici:

Also lautet disse prophecia; is geet gerade zcu ime lande Preussen, also disse prophecia spricht, und hat meer also hundert jar faste also zcu gegangen, das men synt das dy ersten vorstorben synt, dy dis lant ersten besatczt haben, darnoch also balde wart hoffart, geyrickeit und achten der zelickeit der armen Preussen nicht anders denne, das men ir here magk seyn. Got hot lange und vil mannygk jar geduldet und etczliche pfloge und rechunge darummb gethoen, dy zcene wurden etczwan zcugruset, und ire rechter fus vorlemet, ime [grossen] streyte [zcum tannenberge do der hochmeister mit den seynen irslagen wart anno Domini MIIIIcX]. Man see noch zcu, das nicht dy rechte hant, das yst das lant zcu Preussen, das billigk des ganczen ordens rechte hant yst, abgehauen werde. Men irkenne sich noch und

32 T. Nyberg, Birgitta politikern, s. 100.

${ }_{33}^{3}$ Die Ermahnung des Carthäusers, red. Th. Hirsch, w: Scriptores rerum Prussicarum, IV, Lipsk 1870, s. 448-450 (wstęp), s. 450-465 (tekst). 
gedencke mit ernste uff eyne besserunge und wandelunge disses landes. Bey namen spricht und claget disse prophecia, wie men die Preussen beraubet irer freyheit und yst eyn grobes, sy sullen cristen leute seyn und men will yn nicht gonnen cristen recht zcu gebrauchen, und ummb der vortumbten geyrickeit willen gibbet men in eyn recht widder das recht Gotis, und spricht: [...] (Die Ermahnung des Carthäusers, s. 461).

\section{Bitwa pod Grunwaldem (Tannenberg/Žalgiris)}

15 lipca 1410 roku, Zakon Krzyżacki w Prusach został pokonany przez polsko-litewską armię w jednej z największych i najważniejszych bitew średniowiecznej Europy. Na temat tego wydarzenia powstała obszerna literatura a badania prowadzono w wielu krajach i w wielu językach. Ich wyniki znaleźć można na przykład w pracach autorstwa Stefana M. Kuczyńskiego ${ }^{34}$, Svena Ekdahla ${ }^{35}$, Andrzeja Nadolskiego $^{36}$, Mečislovasa Jučasa ${ }^{37}$, czy Williama Urbana ${ }^{38}$. Większość literatury powstałej do roku 1990 odnotowano w dwóch bibliografiach ${ }^{39}$. Podczas gdy wielki mistrz Zakonu Ulrich von Jungingen poległ w walce, zwycięstwo odnieśli król Polski Władysław II Jagiełło i jego kuzyn Vytautas (Witold), wielki książę litewski. Ta decydująca klęska powstrzymała ekspansję Zakonu Krzyżackiego na wschód, a Prusy utraciły pozycję najpotężniejszego państwa w tej części Europy na rzecz Polski i Litwy ${ }^{40}$.

Bitwę stoczono na polach wokół trzech wiosek Tannenberg (Stębark), Grünfelde (Grunwald), i Ludwigsdorf (Łodwigowo) w komturii (Komturei) Osterode (Ostróda) w Prusach. Tannenberg to ostatnia wioska, przez którą przeszła armia Zakonu, stąd

${ }^{34}$ S. M. Kuczyński, Wielka Wojna z Zakonem Krzyżackim w latach 1409-1411, pięć wydań: Warszawa 1955, 1960, 1965, 1980, 1987; tenże, Spór o Grunwald, Warszawa 1972.

${ }^{35}$ S. Ekdahl, Die „Banderia Prutenorum” des Jan Dtugosz - eine Quelle zur Schlacht bei Tannenberg 1410. Untersuchungen zu Aufbau, Entstehung und Quellenwert der Handschrift. Mit einem Anhang: Farbige Abbildungen der 56 Banner, Transkription und Erläuterungen des Textes, Abhandlungen der Akademie der Wissenschaften in Göttingen, Phil.-hist. Klasse, 3. Folge, Nr. 104, Göttingen 1976; tenże, Die Schlacht bei Tannenberg 1410. Quellenkritische Untersuchungen, Bd. I: Einführung und Quellenlage, Berliner Historische Studien, 8, Berlin 1982.

${ }^{36}$ A. Nadolski, Grunwald. Problemy wybrane, Olsztyn 1990; tenże, Grunwald 1410, Warszawa 2003.

${ }^{37}$ M. Jučas, Žalgirio mūšis, Vilnius 1999.

${ }^{38}$ W. Urban, Tannenberg and After. Lithuania, Poland, and the Teutonic Order in search of Immortality. Revised ed., Chicago 2003.

${ }^{39}$ W. Mierzwa, Bibliografia grunwaldzka, Olsztyn 1990; H. Baranowski, I. Czarciński, Bibliografia bitwy pod Grunwaldem i jej tradycji, Toruń 1990. Zob. recenzję S. Ekdahla w ,Zeitschrift für Ostmitteleuropa-Forschung" 45, 1996, 1, s. 118-119. Dostępna jest również znakomita starsza publikacja Stanisława Kujota, Wojna, w: Rok 1410, „Roczniki Towarzystwa Naukowego w Toruniu” 17, Toruń 1910, s. 56-378 (z mapami).

${ }^{40}$ K. Militzer, Die Geschichte des Deutschen Ordens, Stuttgart 2005. Militzer omawia konsekwencje przegranej bitwy w Liwonii i w Rzeszy (s. 143-146). 
nazwa bitwy po niemiecku. Źródła polskie mówią o bitwie pod Grunwaldem, wskazując, że siły polskie maszerowały i walczyły w pobliżu Grünfelde. Po litewsku nazwa brzmi Žalgiris (“Grünwald")

W Liber memorialis klasztoru w Vadstena znajduje się krótka wczesna wzmianka na temat bitwy: Item, eodem anno, in die sancti Iacobi factum est bellum gravissimum inter regem Polonie et Cruciferos Prucie. Ubi devicti sunt Cruciferi, et facta est strages maxima ${ }^{42}$. Data jest błędna i odnosi się do oblężenia głównego zamku Zakonu - Malborka (Marienburg), rozpoczętego 25 lipca $^{43}$.

\section{Polskie plany ufundowania klasztoru Brygidek w Grünfelde (Grunwald)}

Po przytłaczającym zwycięstwie wydawało się oczywiste Polakom i zapewne także Litwinom, że spełniło się objawienie Św. Brygidy o ukaraniu cruciferi. Nie powinno dziwić, że przeorysza klasztoru Brygidek w Gdańsku zaledwie kilka dni po bitwie napisała do króla Polski z prośbą o poparcie i uzyskała przychylną odpowiedź w liście datowanym 6 sierpnia 1410 r. Napisał go podkanclerzy koronny Mikołaj Trąba w obozie pod oblężonym Malborkiem ${ }^{44}$. Wydania odpisu tego listu z kopiarza, przechowywanego obecnie w bibliotece uniwersyteckiej w Uppsali ${ }^{45}$, dokonał Tore Nyberg, który także zajął się kluczowym pytaniem o to, w jakich okolicznościach powstał ten odpis ${ }^{46}$.

Innym bardziej widomym dowodem wdzięczności Polaków wobec Św. Brygidy był królewski zamiar ufundowania klasztoru Brygidek z kościołem wotywnym na polu bitwy. List Jagiełły dotyczący tej sprawy zachował się jako odpis we wspomnianym kopiarzu w Uppsali ${ }^{47}$. Publikowano go trzy razy: najpierw w $1721 \mathrm{r}$. Erik Benzelius Młodszy w swym wydaniu Liber memorialis klasztoru w Vadena ${ }^{48}$, powtórnie w 1910 r., w oparciu o druk Benzeliusa, - Emil Schnippel, który dokonał również tłumaczenia na język niemiecki ${ }^{49}$, a po raz trzeci w 1974 r. - Tore

${ }^{41}$ S. Ekdahl, Tannenberg, Battle of (1410), w: The Crusades. An Encyclopedia, red. A. V. Murray, t. IV, Santa Barbara, California; Denver, Colorado; Oxford, England, 2006, s. 1145-1146.

${ }^{42}$ Diarium Vadstenense. The Memorial Book of Vadstena Abbey. A Critical Edition with an Introduction by C. Gejrot, Acta Universitatis Stockholmiensis. Studia Latina Stockholmiensia, 33, Stockholm 1988, hasło nr.191 s. 159. W Vadstena kodeks ten nazywa się „Liber memorialis”.

${ }^{43}$ Cronica conflictus Wladislai, regis Poloniae, cum cruciferis anno Christi 1410. Z rękopisu Biblioteki Kórnickiej wyd. Zygmunt Celichowski, Poznań 1911, p. 31: „Igitur ipso die sancti Jacobi apostoli [25.7.1410] circumvallit rex castrum Mariemburk."

${ }^{44}$ A więc nie ,im Feldlager bei Grunwald/Tannenberg” jak podano w artykule T. Nyberga, Die Birgittiner, s. 253.

${ }^{45}$ Uppsala, biblioteka uniwersytecka, Codex C 6, fol. 8r.

${ }^{46}$ T. Nyberg, Pierwsze dokumenty Władysława Jagielty dla polskiego klasztory brygidek, ,Zapiski Historyczne" t. 39, 1974, 4, s. 69-73.

${ }^{47}$ Uppsala, biblioteka uniwersytecka, Codex C 6, fol. 8v.

${ }^{48}$ Diarium Vazstenense, red. E. Benzelius Młodszy, Upsaliae 1721, s. 197-198.

${ }^{49}$ E. Schnippel, Das „Kloster von Grünfelde” und die „Kapelle auf dem Streitplatze” bei Tannenberg, „Oberländische Geschichtsblätter” 12, 1910, s. 158-180. Zob. także E. Strehlke, Ein Kloster auf 
Nyberg $^{50}$. To ostatnie, współczesne wydanie uchodzi za najlepsze, z racji dogłębnej analizy rękopisu z Uppsali, która wykonał Nyberg. Udowodnił on, że nazwę geograficzną Grünfelde zapisano jako Grunenvelt w kopiarzu, a nie jak błędnie podali Benzelius a później Schnippel - „Grunnevelt” (i odpowiednio „Grunneveld”) napisano 16 września 1410 r. w obozie pod Malborkiem. Na pewno Jagiełło zdawał sobie wtedy sprawę z konieczności zaprzestania oblężenia zamku (jego armia wycofała się trzy dni później, ale z pewnością chciał zamanifestować swe życzenie oddania hołdu Św. Brygidzie, podziękować Wszechmogącemu za zwycięstwo i zadbać o zbawienie poległych w bitwie.

List królewski stanowił prośbę skierowaną do biskupa Jana z Pomezanii (Johannes Rymann), którego jurysdykcji podlegało pole bitwy. Jagiełło poprosił biskupa, aby zezwolił, zaakceptował i potwierdził ufundowanie klasztoru na odpowiednim miejscu na polu bitwy a ponadto dokonał konsekracji kościoła. Oprócz szczegółów dotyczących planowanej fundacji, list zawiera również ważną wczesną informację o polu bitwy. Klasztor musiał być wzniesiony in loco conflictus nostri, quem cum Cruciferis de Prusia habuimus, dicto Grunenvelt, tzn. obok wsi Grünfelde, $3 \mathrm{~km}$ na południowy zachód od wsi Tannenberg. Jednakże istotne zmiany sytuacji polityczno-wojskowej uniemożliwiły królowi realizację planów: armie litewska i polska opuściły Prusy, okupowane zamki zostały odbite przez siły Zakonu jesienią 1410 r., a pole bitwy znalazło się wkrótce znowu w rękach Krzyżaków.

\section{Krzyżacka Kaplica Najświętszej Marii}

Nie król polski, ale nowo obrany wielki mistrz zakonu krzyżackiego Heinrich von Plauen uzyskał tym samym możność wzniesienia kościeła-monumentu na polu bitwy. Nie było to wszakże opactwo Brygidek, ale kaplica wotywna ku czci Najświętszej Marii, patronki Zakonu ${ }^{52}$. Kaplicę wzniesiono w zupełnie innym miejscu niż to, które niewątpliwie wybrał Jagiełło dla swego planowanego klasztoru: mianowicie miejsce w środku trójkąta, który tworzyły trzy wsie: Tannenberg, Grünfelde i Ludwigsdorf. Historycy i archeologowie snują różne teorie dlaczego właściwie Krzyżacy wybrali to miejsce, które dodatkowo znajdowało się na stoku. Zdaniem autora niniejszego artykułu, podczas bitwy znajdowała się tu w namiocie polowa kaplica Zakonu. Z powodu silnych deszczów w nocy, które trwały aż do rana, miejsce pochyłe było lepsze niż teren płaski, bowiem mogła odpływać stamtąd woda.

\footnotetext{
dem Tannenberger Schlachtfelde, „Altpreußische Monatsschrift” 7, 1970, 1, s. $43-47$ (edycja na s. 46), i St. Kujot, Wojna, s. 375-376.

${ }^{50}$ T. Nyberg, Pierwsze dokumenty, s. 71-72.

${ }^{51}$ Tamże. Więcej, zob. książki S. Kamińskiej, Klasztory brygidek, s. 160-162, i S. Ekdahla, Die Schlacht, s. 133-135.

${ }^{52}$ S. Ekdahl, Die Schlacht, s. 191-192 i 320-369, szczególnie 325-326. Zob. także St. Kujot, Wojna, s. 351-375: Pobożne fundacye i pamiątki bitwy.
} 
Papież Jan XXIII bullą z dnia 6 października 1412 r. dawał sto dni odpustu osobom, które odwiedzą kaplicę w określone dni świąteczne. Tekst bulli opublikowano wraz z niemieckim tłumaczeniem Emila Schnippela w roku $1910^{53}$. Przechowywana jest teraz w Geheimes Staatsarchiv Preußischer Kulturbesitz w Berlinie ${ }^{54}$. Uroczysta konsekracja kaplicy odbyła się 12 marca $1413 \mathrm{r}$. Nie będziemy się tu zajmować historią kaplicy Najświętszej Marii w następnych latach ${ }^{55}$. Ruiny kaplicy zachowały się do dzisiaj. Zarządza nimi fachowo Muzeum Grunwaldzkie ${ }^{56}$.

\section{Lublin jako polska alternatywa}

Gdy nie powiodły się plany wzniesienia klasztoru Brygidek opodal Grünfelde/ Grunwaldu, Jagiełło zwrócił swe zainteresowanie ku Lublinowi z myślą założenia tam klasztoru Brygidek wraz kościołem wotywnym. Powody tego wyboru omówił J. Władziński w książce opublikowanej w roku 1910 z okazji szczególnego jubileuszu grunwaldzkiego w owym roku. Jego zdaniem, król Jagiełło wybrał Lublin ponieważ miasto leżało na szlaku łączącym Polskę z Litwą, jego rodzinnym krajem ${ }^{57}$. Jagiełło (po litewsku Jogaila) był nie tylko królem polski, lecz także princeps supremus Wielkiego Księstwa Litewskiego. Obdarzał zatem to miasto szczególną uwagą, odwiedzając je kilkakrotnie i nadając przywileje. Na przykład nakazał zbudowanie nowego solidnego ratusza na miejscu starego drewnianego, zaś w obrębie murów zamkowych wzniósł kamienną kaplicę Św. Trójcy. Stary kościół był zbudowany z drewna. Odtąd miasto nabrało charakteru ,jagiellońskiego".

Jednym z największych znawców historii opactwa Brygidek Triumphus Mariae wraz kościołem wotywnym był Jan Ambroży Wadowski, który przedstawił ten temat w swej książce o kościołach w Lublinie $(1907)^{58}$. Co się tyczy wieku XVI i następnych okresów, to na uwagę zasługują badania nad historią Zakonu Św. Brygidy

${ }^{53}$ E. Schnippel, Das „, Kloster von Grünfelde“, s. 164-168.

${ }^{54}$ Geheimes Staatsarchiv Preußischer Kulturbesitz, XX. Hauptabteilung Historisches Staatsarchiv Königsberg, Pergamenturkunden, Schieblade 9, Nr 4. Por. S. Ekdahl, Bulle des Papstes Johannes XXIII. Mit Indulgenzerteilung an diejenigen, welche die auf dem Schlachtfeld von Grunwald (Tannenberg) errichtete Kapelle des Deutschen Ordens an bestimmten Festtagen besuchen werden, w: Polen im Zeitalter der Jagiellonen, 1386-1572, (Schallaburg 8. Mai-2. November 1986), Katalog des Niederösterreichischen Landesmuseums, Neue Folge, 171, Wien 1986, s. 522 (foto), p. 523 (tekst).

${ }^{55}$ S. Ekdahl, Die Schlacht; tenże, Ein Inventar der Propstei auf dem Schlachtfeld von Tannenberg aus dem Jahre 1442, „Preußenland” 21, 1983, s.1-9; tenże, Denkmal und Geschichtsideologie im polnisch-preußischen Spannungsfeld, „Jahrbuch für die Geschichte Mittel- und Ostdeutschlands” 35 , Berlin 1986, s. 127-218, szczególnie s. 190-192; tenże, Pobojowisko grunwaldzkie i okolica w XV i XVI stuleciu, ,Studia Grunwaldzkie” 3, Olsztyn 1994, s. 61-118.

${ }^{56}$ Zob. R. Odoj, Grunwald - Vergangenheit und Zukunft eines Nationaldenkmals, Thema Nr 4, Sonderband, red. V. Rodekamp, U. Oehme et al., Leipzig 2005: Academic Colloque. European national monuments in the 21st century - National memory and European identity, Leipzig 15th to 17th October 2003, s. 91-96.

${ }^{57}$ J. Władziński, 1410-1910. Grunwald a kościół Panny Maryi w Lublinie, Lublin 1910, s. 27.

58 J. A. Wadowski, Kościoły lubelskie na podstawie źródet archiwalnych, Kraków 1907. 
w Polsce prowadzone przez szwedzkiego historyka Kościoła Hansa Cnattingiusa $(1972)^{59}$. Równie godne zainteresowania są bez wątpienia książki i artykuły Stefanii Kamińskiej i Tore Nyberga.

Nie dysponujemy informacjami na temat przebiegu negocjacji poprzedzających założenie klasztoru. Najstarszym źródłem jest dokument wystawiony 13 listopada 1412 r., który zachował się w dwóch odpisach. Opublikował go Wadowski ${ }^{60}$ a następnie Nyberg ${ }^{61}$. Treść zbadali starannie Wadowski oraz Kamińska ${ }^{62}$. Wymowa dokumentu jest taka sama jak listu Jagiełły do biskupa Jana z Pomezanii (16 września 1410 r.), i prowadzi logicznie do wniosku, że także ten dokument wystawiono w kancelarii królewskiej. Treść brzmi pokrótce następująco: Kapelan Martin Stoegner z kaplicy Najświętszej Marii, położonej za murami Lublina, scedował kaplicę na prośbę króla i za zgodą miasta na rzecz czcigodnego Jana (Johannesa) Holwassera (Ioanni Hoelwasz procuratori sancte Brygitte de Suecia), ze względu na jego zamiar założenia tam klasztoru Brygidek, któremu wszelkie niezbędne środki zapewni król. Należy to zrobić, aby uczcić niepodzielną Św. Trójcę, Maryję Dziewicę, divisio apostolorum (tzn. rozesłanie apostołów, co miało miejsce 15 lipca, dzień bitwy pod Grunwaldem), świętych Stanisława i Wojciecha (Adalberta) oraz Św. Brygidę i wszystkich świętych. Tym sposobem król i jego poprzednicy oraz wszyscy polegli w walce z Krzyżakami w Prusach mieli być uczczeni na wieczną pamiątkę ${ }^{63}$.

Najwyraźniej, główny klasztor Brygidek w Vadstena wysłał prokuratora już w jesieni 1412 r. (najpóźniej), aby zorganizować założenie klasztoru siostrzanego w Lublinie. Nie stało się to oczywiście nagle i niespodziewanie, ale poprzedzone było nieznanymi nam negocjacjami. Można przypuszczać, że klasztor Brygidek Fons Mariae w Gdańsku odegrał znaczącą rolę w trakcie negocjacji jako mediator między królem a klasztorem w Szwecji. Władziński sugeruje, że pierwsze dwa lata po bitwie poświęcono staraniom na rzecz uzyskania aprobaty fundacji klasztoru ze strony Stolicy Apostolskiej ${ }^{64}$. Wydaje uzasadnione, ponieważ Papież Jan XXIII w tym samym czasie wydał opinię w sprawie prośby Zakonu Krzyżackiego, dotyczącej kaplicy Najświętszej Marii na polu bitwy i wystawił bullę w tej sprawie w listopadzie 1412 roku.

Staropolska tradycja podaje, że kościół wotywny Triumphus Mariae zbudowali jeńcy wojenni ujęci w bitwie w roku $1410^{65}$. Tego twierdzenia nie da się ani potwierdzić ani odrzucić, jednak może być wiarygodne. Zwycięscy Polacy zabrali

${ }^{59}$ H. Cnattingius, Birgittinerorden i Polen, ,Annales Academiae Regiae Scientiarum Upsaliensis. Kungl. Vetenskapssamhällets i Uppsala årsbok”, 16, Stockholm 1972, s. 21-83. Zob. także tenże, Studies in the Order of St. Bridget of Sweden, I, The crisis in the 1420's, Stockholm 1963.

${ }^{60}$ J. A. Wadowski, Kościoły lubelskie, s. 416-417, przyp. 1.

${ }^{61}$ T. Nyberg, Pierwsze dokumenty, s. 72-73.

${ }^{62}$ S. Kamińska, Klasztory brygidek, s. 163-164 (z błędną datą 20 XI 1412 r.).

${ }^{63}$ Tamże. Zob. także T. Nyberg, Pierwsze dokumenty, s. 72-73.

${ }^{64}$ J. Władziński, 1410-1910. Grunwald, s. 30.

65 Tamże, s. 31. 
jeńców do różnych zamków, także do wielkiego zamku w Lublinie ${ }^{66}$. Pierwszy Pokój Toruński z 1 lutego 1411 r. zobowiązywał obie strony do uwolnienia jeńców ${ }^{67}$, ale ponieważ Krzyżacy nie byli w stanie, bądź nie chcieli zapłacić stu tysięcy kóp groszy (na którą to sumę zgodzili się na dzień przez zawarciem traktatu pokojowego) w ciągu oznaczonego czasu jednego roku ${ }^{68}$, późniejsze stosunki stały się napięte. W następnych latach toczyła się zrazu cicha a czasami otwarta wojna między oboma krajami $^{69}$. Polacy oskarżali Krzyżaków o niewypełnienie zobowiązań finansowych; tamci z kolei skarżyli się, że jeńców z armii krzyżackiej nadal więziono Polsce. Prawdopodobnie wykorzystywano ich jako robotników przymusowych przy budowie kościoła w Lublinie.

\section{Problemy z zalożeniem klasztoru}

Ponieważ nie zachował się żaden dokument z informacją na temat założenia klasztoru, w szczególności brak korespondencji w tej sprawie z biskupem krakowskim ${ }^{70}$, można tylko stwierdzić, że musiała mieć miejsce gdzieś między 1412 a 1426 r., gdy klasztor ostatecznie otrzymał rozległe przywileje od polskiego króla. Przeor Holwasser został już odwołany do Vadstena w 1413 r., posunięcie, które zdaniem Kamińskiej, było w sposób oczywisty związane z jego konfliktem z konserwatorem generalnym zakonu, Lucasem Jacobi ${ }^{71}$. Bulla Papieża Urbana VI z 1378 roku uznawała nie tylko klasztor ale także i Zakon Brygidek jako zakon dla kobiet, ale z udziałem mężczyzn, aczkolwiek wedle reguły św. Augustyna ${ }^{72}$. W samym Lublinie Holwasser

66 [Długosz, Annales, X/XI.] Joannis Dlugossii Annales seu Cronicae incliti regni Poloniae, liber decimus et liber undecimus, 1406-1412. Textum recensuit et moderavit D. Turkowska. Moderatore M. Plezia. Commentarios confecerunt C. Baczkowski, F. Sikora, Moderante F. Sikora, Warszawa 1997, S. 125 .

${ }^{67}$ Die Staatsverträge des Deutschen Ordens in Preußen im 15. Jahrhundert. Erster Band (13981437), Zweite verbesserte Aufl., red. Erich Weise, Marburg 1970, s. 86.

${ }^{68}$ Tamże, s. 89-90; M. Pelech, Der Verpflichtungsbrief des Hochmeisters Heinrich von Plauen bezüglich der Bezahlung von 100000 Schock Böhmischer Groschen an den König von Polen vom 31. Januar 1411, „Preußenland” 17, 1979, 4, s. 55-64; S. Ekdahl, Abschrift des Verpflichtungsbriefes des Hochmeisters Heinrich von Plauen bezüglich der Bezahlung von 100000 Schock böhmischer Groschen an den König von Polen vom 31. Januar 1411, w: Polen im Zeitalter der Jagiellonen, s. 520 (foto), s. $521-522$ (tekst); Das Soldbuch des Deutschen Ordens 1410/1411. Die Abrechnungen für die Soldtruppen, ed. S. Ekdahl. Teil I: Text mit Anhang und Erläuterungen, Veröffentlichungen aus den Archiven Preußischer Kulturbesitz, 23/I, Kolonia i Wiedeń 1988, s. 178. - 100.000 kóp groszy czeskich (tj. 6 milionów groszy) odpowiadało wartości 10.000 dobrych rumaków bojowych.

${ }^{69}$ S. Ekdahl, Verträge des Deutschen Ordens mit Söldnerführern aus den ersten Jahrzehnten nach Grunwald, „Questiones Medii Aevi Novae” 11, 2006 (Arms and Armour, red. J. Szymczak), Warszawa 2006, s. 51-95.

${ }^{70}$ S. Kamińska, Klasztory brygidek, s. 164.

${ }^{71}$ Wzmianki na jego temat znajdują się w Diarium Vadstenense; zob. Indeks nazwisk, s. 339.

${ }^{72}$ B. Morris, St Birgitta of Sweden, roz. VII ("The Birgittine Legacy”), s. 160-177, szczególnie s. 161 , 
opowiadał się za założeniem tylko klasztoru żeńskiego, co wywołało spór z Lucasem Jacobi. Konflikt między nimi oparł się nawet o Kurię Rzymską i trwał aż do roku $1424^{73}$. U Długosza, w Liber beneficiorum diocesis Cracoviensis znajdujemy nazwisko następcy Holwassera na stanowisku przeora w Lublinie: „Huszbranth”, czyli Nicolaus Husbrant ${ }^{74}$. Interesujące jest również stwierdzenie Długosza, że Jagiełło powołał niemieckich mnichów i zakonnice z klasztoru Brygidek w Gdańsku do klasztoru w Lublinie: Tandem post plures deliberationes in hac re factas, fratres et sorores ex monasterio Sanctae Brigittae de Gdansk, almanos omnes recepit, et in praefato monasterio locavit ${ }^{75}$. Można to interpretować jako dowód, że nie było ,narodowej” wrogości między Polakami a Niemcami: Jagiełło rozróżniał mieszkańców Prus. Zapewne jednak dałby pierwszeństwo zakonnicom i braciszkom z klasztoru w Vadstena, gdyby to było możliwe. Warto zaznaczyć, że w 1424 roku wyraził życzenie odbycia pielgrzymki do opactwa Brygidek w Gdańsku i korespondował z tej sprawie z niezbyt entuzjastycznie nastawionymi Krzyżakami ${ }^{76}$. Podróż nie doszła jednak do skutku7.

Można wspomnieć, że nie tylko Jagiełło ale także kronikarz i dyplomata Jan Długosz pielęgnowali dobre związki z Lublinem. Piotr Dymmel przedstawia wiarygodne dowody, że ten ostatni wielokrotnie odwiedzał miasto przed 1471 r., z którego to roku pochodzi pierwszy źródłowy dowód pisany. Jako nauczyciel i wychowawca synów Króla Kazimierza Jagiellończyka Długosz spędził z nimi prawie trzy lata od listopada 1473 do września 1476 r. - na zamku w Lublinie. W tym czasie podjął się roli mediatora w konfliktach między mieszkańcami miasta a klasztorem Brygidek. Były to czasy zamętu politycznego, związanego ze konfliktem między Polską a Węgrami o koronę czeską. Stąd też Lublin traktowany był jako dużo spokojniejsze miejsce niż Kraków ${ }^{78}$.

Nawet dobrze zazwyczaj poinformowany Długosz nie daje nam informacji na temat założenia klasztoru w Lublinie. Nie wie, jak się wydaje, o dokumencie z1412 roku, bowiem nie wspomina o nim w swej Liber beneficiorum, czego moglibyśmy oczekiwać. Z przekonaniem pisze, że klasztor założył Jagiełło 1 kwietnia 1426 r.

${ }^{73}$ S. Kamińska, Klasztory brygidek, s. 164-166. Zob. także B. Morris, St Birgitta of Sweden, s. 162. W 1422 Holwasser i inny mnich z zakonu Brygidek skarżyli się na rządzenie klasztorami przez przeoryszę. Następowały również dalsze próby podziału zakonników i zakonnic na zupełnie odrębne społeczności, tak że w końcu sprawą zajął się Synod w Bazylei.(Tamże)

74 [Długosz, Liber beneficiorum, III.] Joannis Dlugosz senioris canonici Cracoviensis Liber beneficiorum diocesis Cracoviensis, 3: Monasteria, Cracow 1864, s. 302. Por. S. Kamińska, Klasztory brygidek, s. 166; T. Nyberg, Nowe prace o zakonie brygidek w Prusach i Rzeczpospolitej, „Zapiski Historyczne" t. 39, 1974, 4, s. 79.

75 Długosz, Liber beneficiorum, III, s. 302.

${ }^{76}$ S. Kamińska, Klasztory brygidek, s. 168.

77 A. Gąsiorowski, Itinerarium Króla Władysława Jagietly 1386-1434, Warszawa 1972, s. 78-96.

${ }^{78}$ P. Dymmel, Związki Jana Dtugosza z Lublinem, „Roczniki Humanistyczne” t. 48, 2000, 2 , s. 99-121. - Autor (S. E.) jest wielce zobowiązany Dr Piotrowi Dymmelowi, Dyrektorowi Archiwum Państwowego w Lublinie, za odniesienia do literatury i źródła, jak też za przesłanie kopii materiałów i zdjęcia kościoła i klasztoru Brygidek w Lublinie. 
(anno Domini 1426 die Lunae, in crastino Paschae, fundat, erigitque) ${ }^{79}$, ale dokument, na który się powołuje i który opublikowano w $1975 \mathrm{r}^{80}$, trudno uznać za dokument fundacyjny. Jest to raczej rozległy przywilej w celu zabezpieczenia materialnego bytu już istniejącego klasztoru ${ }^{81}$.

\section{Przywileje dla klasztoru Triumphus Mariae z 1426, 1431 i 1432 roku}

Nie zachował się oryginalny dokument z 1426 r. Istnieje za to jego odpis z 1607 r., znajdujący się w archiwach metropolii krakowskiej pod nazwą Ingrossatio privilegiorum monialium Lublinensium ${ }^{82}$, którego tu nie zacytujemy, ze względu na jego objętość. Jagiełło darował w nim dwie królewskie wsie Czerniów i Chłopie celem utrzymania klasztoru i zwolnił je ze wszystkich powinności. Ciekawostką jest następujące sformułowanie na temat bitwy pod Grunwaldem: ... quae gessimus pro patria et gente nostra contra Cruciferos et Prussiae hostes nostros, ....

Powody, dla których upłynęło tyle czasu - 14 lat - zanim przywilej zrealizowano, omówiła Stefania Kamińska ${ }^{83}$, a także Tore Nyberg w recenzji z jej książki ${ }^{84}$, lecz nie będziemy tej sprawy przedstawiać tu w szczegółach. W swej recenzji Nyberg odnosi się raczej sceptycznie do prób Kamińskiej powiązania wielkiego zainteresowania Króla Unii Kalmarskiej (Związku Skandynawskiego) Eryka Pomorskiego Zakonem Brygidek ${ }^{85}$ i kontaktami z Jagiełłą, z przywilejem tego ostatniego nadanym klasztorowi w Lublinie. Nyberg powołuje się na artykuł Zenona Huberta Nowaka, wedle którego około roku 1420 nabrała już kształtu nowa konstelacja polityczna. Król Węgier Zygmunt Luksemburski i Eryk Pomorski działali razem przeciwko Królowi Polski ${ }^{86}$. W późniejszej pracy z roku 1999 Nyberg zmienił jednak nieco swój pogląd, także powołując się na artykuły autorstwa Z. H. Nowaka: „Prawdopodobnie nie bez związku z ustanowionymi wtedy stosunkami, toczyły się w 1418/19 rokowania na szczeblu politycznym między Polską a Erykiem Pomorskim, ale nie

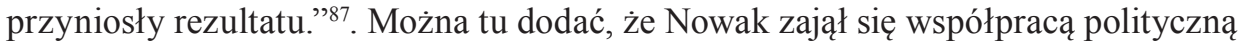

${ }^{79}$ Długosz, Liber beneficiorum, III, s. 302.

${ }^{80}$ Zbiór dokumentów małopolskich, red. I. Sulkowska-Kuraś i S. Kuraś. VII: Dokumenty Króla Władysława Jagietly z lat 1418-1434, Wrocław, Warszawa, Kraków, Gdańsk 1975, nr 1996, s. 201-204.

${ }^{81}$ Można przytoczyć określenie T. Nyberga „Schon 1412 machte Władysław Jagiełło die erste Stiftung für ein Birgittenkloster außerhalb Lublins” T. Nyberg, Der Deutsche Orden, s. 177.

${ }^{82}$ Zbiór dokumentów małopolskich, VII, s. 201; J. A. Wadowski, Kościoły lubelskie, s. 418-419, przyp. 1.

${ }^{83}$ S. Kamińska, Klasztory brygidek, s. 167-169.

84 T. Nyberg, Nowe prace, s. 78-80.

${ }^{85}$ W 1416 Eryk pomorski założył klasztor Maribo na wyspie Lolland w Danii.

${ }^{86}$ Z. [H.] Nowak, Przymierze Polski i Litwy z państwami unii kalmarskiej w 1419 r., „Zapiski Historyczne" t. 34, 1969, s. 45-78. T. Nyberg, Nowe prace, s. 79.

87 T. Nyberg, Der Deutsche Orden und der Birgittenorden, w Der Deutsche Orden in der Zeit der Kalmarer Union 1397-1521, red. Z. H. Nowak, R. Czaja, Universitas Nicolai Copernici. Ordines militares, X, Toruń 1999, s. 169-180, cytat na s. 177 (por. tamże, s. 181, przyp. 16). 
między Unią Kalmarską (Związkiem Skandynawskim) a dwoma krajami Unii Polsko-Litewskiej w latach 1411-1425 w jednej ze swych książek w $1996^{88}$.

Pod koniec swego życia, Jagiełło nadał jeszcze dwa przywileje klasztorowi Brygidek w Lublinie. 21 września 1431 zezwolił na zatrudnienie dwóch rybaków ${ }^{89}$, a rok później, 22 września 1432, przywilej z 1426 został rozszerzony o trzecią wieś i ziemie darowane przez osobę nazwiskiem Nicolas [Mikołaj] Tłusto. Zwolniono je od wszelkich podatków i powinności ${ }^{90}$. To wyraźnie pokazuje, że król nie zapomniał o proroctwie szwedzkiej świętej i był za nie wdzięczny.

\section{Podsumowanie}

Nie jest naszym zamiarem opisywanie dalszego rozwoju klasztoru Triumphus Mariae ${ }^{91}$, jego związków z klasztorem Fons Mariae w Gdańsku i z zakładaniem wielu pobocznych klasztorów w różnych częściach Polski i Wielkiego Księstwa Litewskiego. Położone one były w Samborze, Lwowie i Sokalu w Galicji, w Lipiu na południe od Warszawy, oraz bardziej na wschód - w Brześciu Litewskim, Łucku i Grodnie ${ }^{92}$. Wedle Stefanii Kamińskiej był także klasztor Brygidek w Wilnie ${ }^{93}$. Wszystkie zostały założone w pierwszej połowie XVII wieku, gdy kontrreformacja (restauracja katolicka) uratowała Zakon Brygidek w Polsce przed rozwiązaniem. Oczywiście, Władziński reprezentuje pogląd, że Zakon Św. Brygidy nie cieszył się od początku sympatią ze względu na zbyt surową regułę - nie zdołał dlatego przyciągnąć wielu zwolenników, czy się znacznie rozwinąc ${ }^{94}$. Istotnie, regula Sancti Salvatoris nakazywał mniszkom bardzo ścisłe odosobnienie. Kontakt ze światem zewnętrznym był zredukowany do minimum. Jest jednakże rzeczą oczywistą, że Triumphus Mariae, sprowadzony wtedy tylko do klasztoru dla zakonnic, od roku 1600 był wzorem

${ }^{88}$ Z. H. Nowak, Wspótpraca polityczna państw unii polsko-litewskiej i unii kalmarskiej w latach 1411-1425, Toruń 1996.

${ }^{89}$ Zbiór dokumentów małopolskich, VII, nr 2085, s. 340-341.

${ }^{90}$ Tamże, nr 2113, s. 374-377. Zob. także Długosz, Liber beneficiorum, III, s. 302-307.

${ }^{91}$ Istnieją cztery zapisy o klasztorze Triumphus Mariae w Liber memorialis opactwa w Vadstena, wszystkie datujące się z lat 20-tych XVI w. Brat Andreas Matthei z polskiego klasztoru przebywał w Vadstena przez prawie rok i domagał się, aby przysłano kilku braci ,pro reformacione monasterii sui et ordinis nostri in Triumpho Marie in terra Polonie situati”. Nastepnie Andreas wraz dwoma innymi zakonnikami udał się do Polski 16 maja 1511. Jednakże ich wysiłki w celu reformowania klasztoru nie powiodły się, ponieważ nie układały się ich stosunki i dwaj szwedzcy bracia wrócili do Vadstena 28 czerwca 1513. Diarium Vadstenense, nr 1012:2 (s. 293), 1021 (s. 294). Zob. także nr 1008:2 (s. 292), 1039:2 (s. 298).

92 T. Nyberg, Birgittinische Klostergründungen; S. Kamińska, Klasztory brygidek, s. 184-187; H. Cnattingius, Birgittinerorden i Polen, s. 64-83; U. Sander Olsen, Birgittinorden och dess grenar, w: Birgitta av Vadstena, s. 380, 387.

${ }_{93}$ S. Kamińska, Klasztory brygidek, s. 187.

94 J. Władziński, 1410-1910. Grunwald, s. 29: „A od pierwszych chwil swego istnienia zakon św. Brygidy nie cieszył się sympatją. Surowa jego reguła nie jednała mu zwolenników, ztąd nigdy zbytnio się nie rozwinąt.“ 
o wyraźnie arystokratycznym charakterze i znakomitej reputacji. Rozkwitał szczególnie pod energicznymi i zręcznymi rządami przeoryszy Agnieszki Jastkowskiej na przełomie XVI i XVII w. Klasztor Brygidek pod wezwaniem Najświętszej Marii istniał do roku 1860, będąc przez długi czas źródłem siły religijnej w Polsce. Budynki kościoła i klasztoru zachowały się do dzisiaj.

Kiedy w drugiej połowie lat 1340-tych Birgitta Birgersdotter otrzymała pierwsze przesłanie od Jezusa Chrystusa dotyczące przyszłego ukarania Krzyżaków cruciferi, na pewno nie spodziewała się, jakie będą tego konsekwencje. Impuls miał przyjść do Polski ze Szwecji poprzez Prusy Krzyżaków. Objawienia Brygidy przyniosły zmiany religijne i kulturowe, których reperkusje przetrwały częściowo przez ponad połowę tysiąclecia.

Tłumaczył Jerzy Adamko 